\title{
'Thinking from a place called London': The Metropolis and Colonial Culture, 1837-1907
}

\section{FELICITY BARNES}

In April 1907, at the Colonial Conference in London, the premiers of the white self-governing colonies met with members of the imperial government to reconcile two apparently conflicting objectives: to gain greater acknowledgement of their de facto political autonomy, and commitment to strengthening imperial unity. ${ }^{1}$ The outcomes of this conference tend to be cast in constitutional and political terms, but this process also renegotiated the cultural boundaries of empire. The white settler colonies sought to clarify their position within the empire, by, on the one hand, asserting equal status with Britain, and, on the other, emphasizing the distinction between themselves and the dependent colonies. ${ }^{2}$ In doing so they invoked and reinforced a hierarchical version of empire. This hierarchy, underpinned by ideas of separation and similarity, would be expressed vividly in the conference's outcomes, first in the rejection of the term 'colonial' as a name for future conferences. These were redesignated, inaccurately, as 'imperial', not 'colonial', elevating their status as it narrowed their participation. ${ }^{3}$ 'Imperial' might be metropolitan, but 'colonial' was always peripheral. Whilst the first Colonial Conference, held in 1887, had included Crown colonies along with the self-governing kinds, ${ }^{4} 20$ years later the former were no longer invited, and India, or, more precisely, the India Office and its officials, was only a marginal presence..$^{5}$ As wider participation declined, imperial government involvement increased. From 1907 the conference was to be chaired by the British prime minister. This pattern was repeated in changes to the Colonial Office itself. The self-governing colonies used the same conference to press for a separate dominion, not colonial, form of imperial administration.

But it was not only the status of the conference that would be elevated by a touch of imperial rebranding. Canadian Premier Sir Wilfrid Laurier noted, 'We have passed the state when the term 'colony' could be applied to Canada'. ${ }^{6}$ Canada was not alone. It was generally acknowledged amongst all conference participants that their particular colonies - Australia, New Zealand, Newfoundland, the Cape Colony, Transvaal and Natal - had also transcended the colonial state. Something new was required, and the 
conference turned its attention to inventing a term to describe their special place in the empire. Laurier "wish[ed] we could drop the word "colonies" and try to invent something which would strike the imagination more'? Joseph Ward, who had initiated the debate, obliged with 'States of Empire', which was striking, if only for its ostentation. ${ }^{8}$ This and other potential replacements for 'colony' were debated, dissected and discarded, their meanings checked for inappropriate inference and subjected to anxious calibration. 'Dominions beyond the seas' was rejected because Laurier felt it ran the risk, unlikely as it seems, of 'equating Canada with places like Trinidad'. ${ }^{9}$ Finally, it was the Australian premier, Alfred Deakin, along with Laurier, who finessed issues of status and empire, similarity and separation, with the term 'Dominion'. Its greatest virtue seemed to be its vagueness - 'a general term that covers many words which it is not possible to define otherwise'- but its use was clear. ${ }^{10}$ It was limited to the former white colonies of settlement.

New Zealand's adoption of Dominion status was, therefore, a 'national' change produced in and by, an imperial, metropolitan context. New Zealand's decision to incorporate 'Dominion' into the country's official title acted as a constitutional solution to imperial status anxiety as much as being indicative of any imperial or national ambition. Canada and Australia already had titles that distinguished them from the 'colonies', one as the first Dominion, proclaimed in 1867, and the other as a Commonwealth since 1901. It seemed likely that the South African colonies too would soon be united under some new title. Dominion status linked New Zealand with the other self-governing colonies, and underlined its position as part of the white empire. At the same time it separated New Zealand from the dependent version. Ward himself stressed this, explaining that it was 'more important than the mere change of name that we should get out of the ruck of dependencies which call themselves colonies.'. ${ }^{11}$

Having effected a transformation in the nature of New Zealand's identity, Ward sailed home with the newly fashioned version concealed as a 'surprise packet', like a magician with a trick up his sleeve, anticipating an excited and grateful public. ${ }^{12}$ But the surprise was on him. Sir Joseph's magic trick did not delight the country. The reconfiguration of New Zealand as Dominion was seen initially as hollow, gauche and presumptuous: like 'a very small man wearing a very large hat', as one politician described it. ${ }^{13}$ Stealing Canada's title was considered ill-mannered and ill-advised, as New Zealand lacked both Canada's size and its seniority. The press, poor poets, and various correspondents speculated on one aspect of identity transformation: whether they would become Dominionites or Dominoes. ${ }^{14}$ Criticism receded somewhat in the interim before the official inauguration of Dominion Day in September, when elaborate celebrations in the main centres drew large crowds. But whilst many took trams into central Dunedin to take part, even 
larger crowds took them to the beach at St Clair. ${ }^{15}$ There was reportedly 'not much excitement' in Paeroa, although things may have been livelier in Kaponga, where residents drank the health of two new Dominions, one the country, and the other a new hotel ${ }^{16}$ Though The Times in London rejoiced that New Zealand had been raised to the status of Dominion, in Foxton, the town clerk read the proclamation to one resident and a reporter. ${ }^{17}$ This crowd raised, understandably, only 'a faint cheer for the Dominion'. ${ }^{18}$

Cheering for the Dominion was destined to grow even fainter. Anniversary celebrations in 1908 fell on a Saturday. The New Zealand Shopkeepers' Association could not 'see its way to invite shopkeepers to close' on their best trading day, ${ }^{19}$ while in Blenheim, school children received their Dominion Day commemorative medals a day early so that they would not have to go to school on a Saturday. ${ }^{20}$ Even brass bands were difficult to muster, as their working members stood to lose a half-day's pay. ${ }^{21}$ The Prime Minister's office seems to have applied a little pressure to local councils, but with mixed success. Whilst Rotorua would 'heartily cooperate', Devonport was 'indefinite', and Greymouth, perhaps hoping to escape further searching official inquiry, offered to 'do their best'. ${ }^{22}$ In 1909 Dominion Day fell on a Sunday, meaning bands and entertainment were inappropriate. By 1910, people in Paeroa did not 'bother their heads about the holiday'. ${ }^{23}$ Wanganui's bunting was meagre. ${ }^{24}$ It was a 'Dull day in the Dominion'.25

Ward's reimagining of New Zealand as a Dominion is one of the dry wells of New Zealand's cultural history. Read within the borders of a national history, the dull day in the Dominion seems to provide more evidence of the lamentably slow death of New Zealand's connections with Britain and its imperial world. ${ }^{26}$ Curiously, in newer histories it becomes slight proof of the opposite, but in either case it is little more than a historical grace note. ${ }^{27}$ Read through the lens of cultural colonization, even these slender meanings are blurred. Renaming New Zealand 'Dominion' is an acute example of a literature of occupation, a case of textual colonization writ large. But public ambivalence seems to render it an empty gesture, the cultural equivalent of Abel Tasman's voyage. As some newspapers smugly reported, nothing appeared to have changed. ${ }^{28}$ But it had. We are just looking in the wrong time and in the wrong place. To understand what had changed, we need to look past the local strands of limp bunting, and consider instead the way that New Zealand identity was formed by its metropolitan connections and enmeshed in the webs of imperial meaning. Dominion status provided an official label for an identity that had been under development for some time..$^{29}$ It was, like other New Zealand identities, fashioned in, and with, the metropolis, in response to the exigencies of empire. Truth identified this dynamic in 1910 when it derided Dominion Day as another unfortunate example of New Zealand's tendency 'to think from a place called London'. ${ }^{30}$ 
Though Truth might not approve, one aim of this article is to explore the historiographical effects of thinking from London. The first of these is self-evident. Reconsidering the metropolis's role in forming one of New Zealand's identities is consistent with the much broader and longer-term project of 'decentering the nation'. ${ }^{31}$ It conforms in two ways: first, by making national identities the archive, rather than the object, of inquiry, the 'nation' becomes part of our cultural history, not the purpose of it. Second, London as a site for the formation of a 'New Zealand identity' undercuts the idea of nation as a discrete entity. Transnational approaches can have similar decentering effects. However, rethinking New Zealand's relationship with London has more in common with work that focuses on space and mobility. Tony Ballantyne has recently argued that attending to history's 'complex patterns of mobility and circulation ... might produce some very useful reassessments of our past'. ${ }^{32}$ The relationship between London and New Zealand, with its particular and intense circulation of people, material, practices and ideas (the miscellany of culture), is an obvious opportunity for such a reassessment. James Belich characterized one formulation as recolonization. ${ }^{33}$

This article adopts and extends these ideas. It enriches the idea of circulation by tracing the articulation of identity across a variety of forms as well as spaces, from official pronouncements to grilled chops. This highlights different types of circulation, whilst not attempting to ascribe particular importance to their status, as systems or networks, for example. ${ }^{34}$ Instead, it draws attention to their interrelationships. Dominion status and a Dominion hotel are more than just a fortunate textual juxtaposition; they remind us that similar cultural meanings could be generated and articulated through different, yet intertwined, systems. They also produced a very distinct and underestimated form of cultural mobility. One of the key characteristics of New Zealand's metropolitan relationship was the cultural reconstruction of time and space: imagined movement, rather than the real thing. New Zealanders did not have to be in London to imagine it as their city too; conversely, for intending migrants, formal migration literature could imaginatively minimize the distance, cultural and otherwise, between New Zealand and Britain.

Of course, the reassertion of metropolitan, or British, links, especially into the twentieth century, shares with Peter Gibbons's cultural colonization an interest in redefining the places and practices of colonialism. ${ }^{35}$ But though Gibbons's work and other Saidian-influenced postcolonial approaches have widened and deepened our understanding of some of these practices, the relationship between colony and metropolis has remained unexamined. In these new histories, as in older narratives of 'nation', the colony's connections to the metropole mark a form of cultural immaturity or colonial 
dependence. ${ }^{36}$ This has the twofold effect of effacing the colonizing agency of these linkages, and naturalizing 'Britishness' as a form of identity. This lacuna has been explained as the product of scholarly discomfort: identifying the gap, Katie Pickles has recently suggested that scholars have found this colonial, and imperial, form 'awkward' and that some 'fear exhuming a British past has the potential to make it "more unified, coherent and posthumously complete'. ${ }^{37}$ However, the reverse may be the case. Adele Perry has argued in the case of British world studies ${ }^{38}$ (one target of this critique), that 'The simultaneous presence and mutability of the British world comes into sharpest relief when we bring together the histories of local colonial projects and metropolitan politics, cultures, and discourses. ${ }^{39}$ The faint cheers in Foxton come to mind. Integrating metropolitan and local histories in this case deconstructs rather than resurrects a coherent 'Britishness'. Further, one of the most interesting possibilities for studies of Britishness in colonial settings is the way they may have produced their own versions, rather than had models imposed on them, and how these may have conflicted with, augmented, or remodelled versions created in the centre itself. ${ }^{40}$ This, of course, reminds us that Britishness, like New Zealandness, was a contingent cultural form. But the idea of 'New Zealand', variously located in time and space, is the main focus here.

'Thinking from a place called London' had been shaping New Zealand, in different ways, and for different purposes, for a very long time. In 1837, 70 years before the Dominion of New Zealand was officially produced in the metropolis, another version of New Zealand was under construction. This time, it was a fringe of empire created on the fringe of polite society. Its location, Leicester Square, was less salubrious than the Colonial Office. A 'View of the Bay of Islands' appeared in Robert Burford's famous Panorama Theatre, jostling for attention with diversions and amusements of questionable propriety, including a gun range where Queen Victoria's first aspiring assassin would practice. The Panorama's architect, a fringe dweller of questionable propriety himself, was Edward Gibbon Wakefield, and his purpose was to create New Zealand as a colony for settlement and investment. At this time, New Zealand was already located in the metropolis, a bit player in a broader discourse that constructed raw edges of empire as zones of otherness. These edges, products of empire's predilection for classification and order, were imagined as backward places that existed outside of time. Anne McClintock has labelled these constructions anachronistic spaces, living examples of the past that, unlike the centre, had failed to progress. ${ }^{41}$ This contrast, of course, acted to confirm the centre's own position as civilized. As Alan Lester notes, British colonies became 'the most significant locales for the production of such imageries' for the metropolitan imagination. ${ }^{42}$ 
To reform New Zealand's identity, Wakefield not only commandeered metropolitan media, he commandeered aspects of metropolitan culture. On the panorama's gigantic canvases, strange canoes shared a painted harbour with whaling ships, while HMS Rattlesnake (whose captain, William Hobson, imagined a considerably less British version of colonial New Zealand) lay at anchor. On land, native huts were complemented by a 'village, truly English in its aspect'. Scenes of native dancing, described as typical of a 'barbarous nation', were offset by a picture of the Reverend Samuel Marsden himself, 'expound[ing] the truths of the Scripture' to other Māori. The Morning Post described him as an 'agreeable foil' to the 'Ethiopian-like skin and savage look of his auditors'. The facile association of Ethiopian and Māori hints at the undifferentiated discourse of otherness in which New Zealand was caught. ${ }^{43}$ However, the savage appearance may have been overstated. The panorama's paintings, which have not survived, were based on sketches by Augustus Earle, and Leonard Bell suggests that when the images were used in later New Zealand Company propaganda, Māori were modified so they appeared 'almost Victorians transposed to the South Seas'. ${ }^{44}$

The co-option of symbols of Britishness - church, navy, commerce and rural village life - were attempts at overwriting New Zealand's position in anachronistic time and space. Strategies of similarity and separation, akin to those later deployed in the creation of Dominion status, were used to move New Zealand away from the lower rungs of imperial time and space. Their use is graphically demonstrated in the accompanying descriptive guide, the only surviving visual record of the panorama (Figure 1). ${ }^{45}$ It was divided in two horizontally. The lower drawing produced a 'native' New Zealand, with tattooing, weaving, warriors, slaves, fern roots and dancing: exotic fodder, like the examples of native costume hung around the walls, for the curious spectator. But the upper diagram reveals a separate landscape transformed by civilizing Britishness. In this view of the Bay of Islands, almost all traces of a barbarous nation have vanished, the one reminder of its presence visibly 'civilized'. Left on a hillside, overlooking the tranquil, settled harbour, were some Māori 'dressed in European costume' ${ }^{46}$ These are the Māori Marsden was shown preaching to, his civilizing powers of spiritual conversion pointedly accompanied by powers of sartorial conversion. The visual separation, apparently a coincidence caused by the conventional layout of panorama guides, would of course have been deliberate, not only in the selection of 'civilized' New Zealand as the upper layer of the guide, but in the design of the panorama itself. The canvas was circular, so the upper and lower diagrams of the guide represent two halves of the circle. This means 'savage' New Zealand was confined to one portion. Panoramas gave viewers a sense of visual control: here, British civilization would have appeared to have literally encircled the old frontier. 
One panorama, of course, does not make a colony. However, these strategies were integral to the rapidly growing genre of immigration propaganda, which, as Robert Grant has noted, routinely used rhetorical devices that specifically referenced Britishness to tame wild frontiers. ${ }^{47}$ Samuel Brees repeated the panorama exercise between 1849 and 1851, but other forms would continue to use metropolitan locations and discourse to create New Zealand as British colony until the end of the 1870s. These early representations of New Zealand, amplified by similar representations of other colonies, were powerful instruments, even if the place they imagined was to take on unanticipated forms. But identities are contingent, and after that time immigration was no longer the most important component in the production of New Zealand. From the 1880s, New Zealand assumed its recolonial role as producer of commodities for the metropolis, rather than as commodity itself. As a consequence, New Zealand's identity was transformed from British colony to British farming hinterland. The use of metropolitan culture changed too. Old, colonial New Zealand had relocated it to create 'Greater Britain' or a 'Britain of the South'. The new version of New Zealand integrated it, using metropolitan time and space as its own. Thinking from London now meant thinking with London. This is the time and place where we can begin to look for the formation of 'Dominionness'. The orderly and ordering spaces of metropolitan exhibitions were key locations to articulate and develop this new identity.

At first, however, these served to only confirm New Zealand's position on the periphery. From 1851 until 1884, New Zealand was represented by its natural history, natural resources and ethnography. At the Crystal Palace, amongst the dazzling displays of the industries of all nations, New Zealand was represented by a modest selection of raw materials and exhibits, including a model of a 'New Zealand war pah', and a lithograph of a native village, included as optimistic indicators of native potential. ${ }^{48}$ Eleven years later, at the 1862 London International Exhibition, small displays of gold, kauri gum, flax and wood were accompanied by scenic photographs and paintings, including Charles Heaphy's paintings of the thermal regions. ${ }^{49}$ In Vienna in 1873 the usual selections of quartz, wool, coal and flax were framed by Julius von Haast's moa skeletons. ${ }^{50}$ Fine arts and manufactures, the signature symbols of metropolitan culture, were almost entirely absent: a preliminary exhibition held in Christchurch to source worthy exhibits for Vienna yielded, amongst similar items, five field drains, four flower pots, three pickle jars, one cheese, some tins of meat and a case of glue. ${ }^{51}$ Even Sir Joseph Ward, a wizard with transformations, would have had trouble

Following pages: Figure 1. Explanation of a View of the Bay of Islands, New Zealand, exhibiting in the panorama, Leicester Square by Robert Burford, ?1838. Special Collections, The University of Auckland Library. 


\section{Fy}
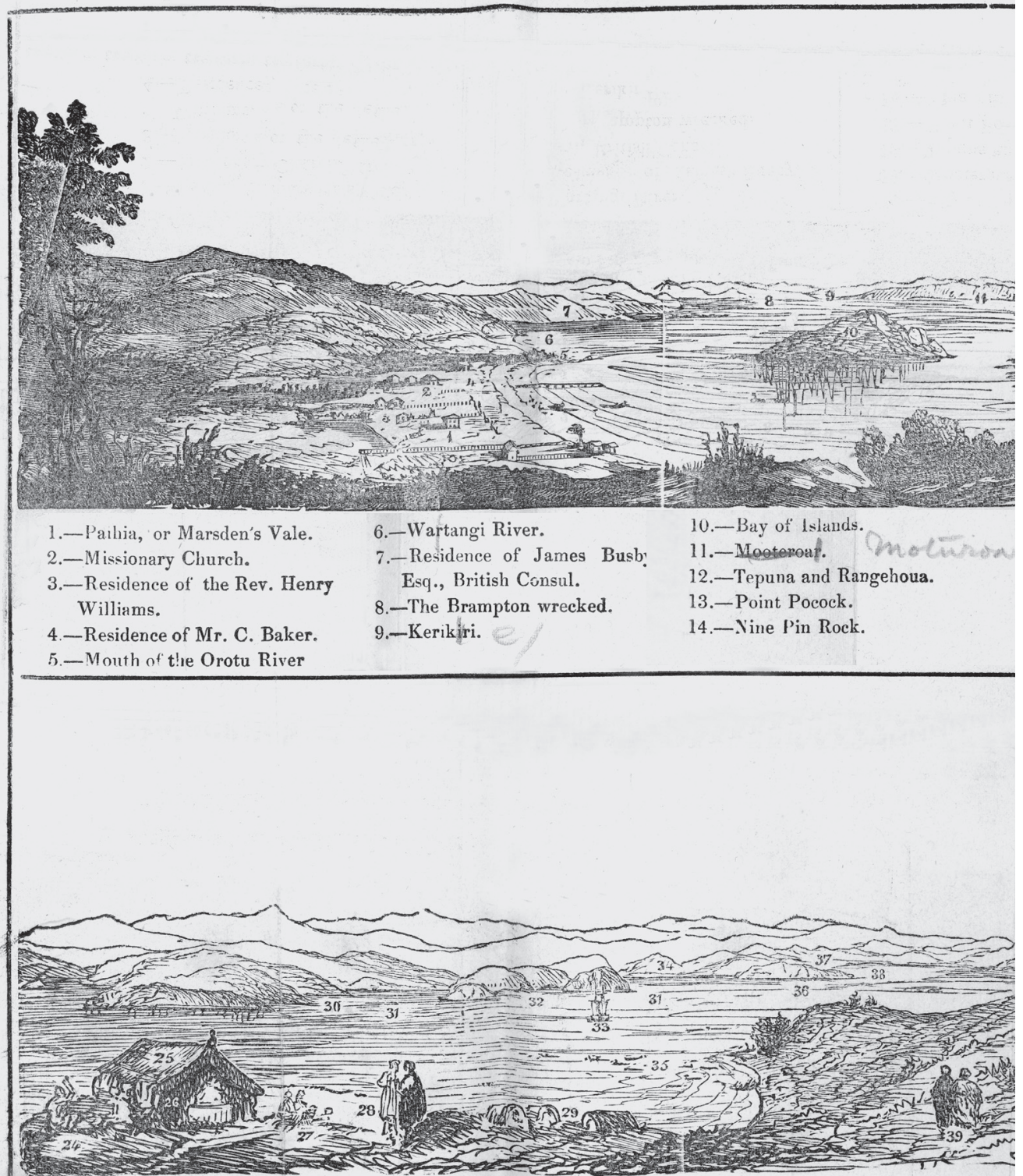

24.-Preparing the Fern Root.

25.-Native Huts.

26.-A Woman Wearing Mats.

27. -Tattooing.

28.-Warriors.
29.-Huts of the Slaves.

30.-Residence of Mr. Mair, Post $n$ aster.

31. The Shore called the Wy Cadde
32. - Residence of Capt. Wright.

33 - Store Ship taking in Spars.

34.-Residence of Capt. Clendon.

35. - War Canoes.

36. - A Native Par. 


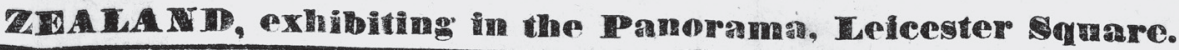
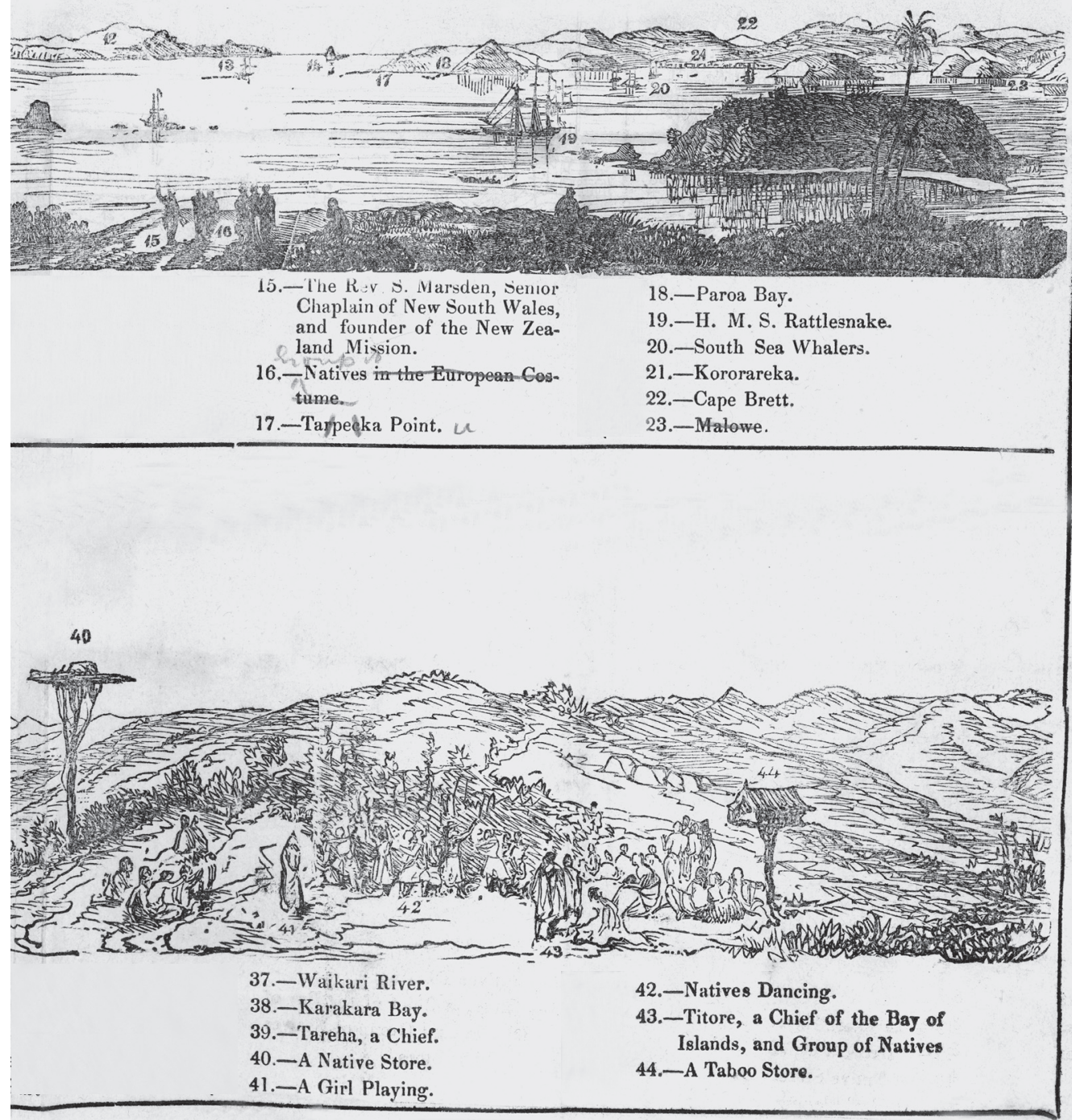
conjuring a modern Dominion from these materials. Should visitors have needed any further reminders of New Zealand's peripheral status, there were the usual 'boiling mud cones', wild west-coast scenery, and pictures of the Wairau massacre. ${ }^{52}$ Despite the colonial rhetoric of progress, New Zealand's first appearances in the thoroughly modern space of exhibition halls were, contrarily, object lessons in the formulation of anachronistic space.

This space was rapidly, if unexpectedly, reformed by the development of the refrigerated pastoral industry from the 1880s. Earlier, New Zealand lacked signature symbols of metropolitan culture: Julius Vogel, in 1875, cautioned against attempting to juxtapose New Zealand's manufactures with those of other countries. ${ }^{53}$ But the evocation of British-styled farms worked almost as well to articulate similarity with the metropolis and separation from the periphery. Similarity was obvious enough in the products themselves - meat, butter, cheese, along with wheat and wool were all familiar products of actual British farms. They formed the understated opposite of products like tea and sugar, which, though thoroughly domesticated by use, retained an exotic image. These British-like farm products quickly became the focus of the exhibits, pushing moa bones, quartz and Māori conveniently to the margins. In 1884, just two years after the inaugural shipment of frozen meat, over 100,000 chops were sold at the International Health Exhibition at South Kensington, a fitting prelude to the development of New Zealand as metropolitan farm. ${ }^{54}$ The 'New Zealand Grill' sold 800 to 1000 cooked chops each day, and the butcher's shop was also 'doing a roaring trade'. ${ }^{55}$ In 1886, at the Colonial and Indian Exhibition, both New Zealand and Australia provided frozen meat and produce for the exhibition restaurants, although these were sited at the Colonial Market rather than within the New Zealand exhibit itself. ${ }^{56}$ That exhibit combined commodities and curios: the catalogue acknowledged the growing importance of New Zealand's farm products, alongside displays of birds, lizards, moa, 'Maori curiosities', geology, fish, invertebrates, tuatara and a red cod. ${ }^{57}$ The guidebook noted New Zealand's mineral wealth, but concluded: 'farm products form the chief source of wealth of the colony'. ${ }^{8}$ By the time New Zealand had its first outing as a Dominion at the Franco-British Exhibition of 1908, the exhibits were 'organised mainly to demonstrate the natural resources and productive economy of the Dominion'.59 By 1911 New Zealand was represented by four courts - 'Sport and Tourism', 'Timber and Minerals', 'Wool, Grain, and General Exhibits' and 'Refrigeration' - two of which focused on the farm. ${ }^{60}$

This changing space was accompanied by a shift in time. The 'British' New Zealand farm was created on a land recently cleared of both bush and history. Māori, as markers of the peripheral past, were whitened, minimized and contained. The Colonial and Indian Exhibition guidebook 
of 1886 assured readers: 'there are, it is estimated, about 44,000 Maoris or aboriginal inhabitants. A great part of these are given to the same peaceful pursuits as the European settlers - growing wheat, potatoes etc and keeping cattle. Every year is increasing this' ${ }^{61}{ }^{61}$ This verbal picture of a small, docile and Europeanized indigenous population was reassuring. The court itself only included Māori exhibits 'so as to show what New Zealand was like in the Old Maori times and then to show what it is doing now'. ${ }^{62}$ Underlining both the passing and pastness of Māori, organizers used wax figures rather than live exhibits of native people favoured by other colonies. These, and a carved tomb placed in the fernery, were illustrative of Māori as a dying race, belonging 'to a past which is as dead as the age of the cave-men and lakedwellers'. ${ }^{63}$ That past was briefly resuscitated in 1911, when live Māori were to be included in the Festival of Empire. But their involvement was safely contained in 'Old' New Zealand. They were to appear in a re-enactment of the signing of the Treaty of Waitangi; for the rest of the time they were to be consigned to really living in the past, in a model Māori village. ${ }^{64}$ This proved difficult, and so,for the next great imperial pageant, at Wembley in 1924, Londoners dressed up to play the Māori. ${ }^{65}$

Excising the past subverts the conventional construction of nationalism, which, as Benedict Anderson has noted, gains legitimacy when it seems to 'loom out of an immemorial past'. ${ }^{66}$ Legitimacy in the Dominion case was, instead, provided by a borrowed metropolitan past. The New Zealand farm idealized a mythic rural England, summoning up yeoman and milkmaids along with wheatfields and orchards. Visitors who took a ride on the 1911 festival's 'All Red' railway saw the 'sheep farms of New Zealand' which became part of a bucolic imperial blend as 'the flock and herd would stretch away beyond them. The apples would be plucked from the trees, and the orchards would stretch away into the distance. ${ }^{67}$ Time was rearranged to imply similarity in another way. Refrigeration machinery and cross-sections of ships' holds created New Zealand's farming as super-modern, neatly avoiding any sense of rural backwardness. It was a trip through time and space. The railway passed that model Māori village but also docks 'where steamers may be seen taking cargoes of grain, wool, and mutton for shipment to Great Britain'. ${ }^{68}$

The physical arrangement of exhibitions was also marked by strategies of separation and similarity. The white settler colonies were grouped together. At the Colonial and Indian Exhibition, visitors could move from the exotica of India to the Australasian sections, offering 'science, landscape painting, manufactures, minerals, wool, and wood', in which 'one met with no Oriental, but a sturdy British element'. ${ }^{69}$ At the multi-imperial Franco-British Exhibition of 1908 the white Dominions were arranged together, even if it was along the unfortunately titled 'Avenue of the Colonies'. This distinction 
continued in pavilion design. Whilst local architectural styles could be included in dependent-colony pavilions, the Dominions preferred to promote 'civilization'. Pavilions for the 1911 exhibition were three-quarter-size scale models of their parliaments, classically-styled buildings embodying the very nature of 'self-governing' Dominions, relentlessly positioning their present in a civilized, not primitive, past.

These experiments in time and space were not simply representations to be found only in London exhibition halls. Around this period, 'Old New Zealand' began to fall out of favour at home. Natives' Associations waxed and waned, a fashion for co-opting Māori motifs in furniture styles or house names passed, and high cultural hopes for 'national' literature based on fanciful appropriation of Māori culture were also laid to rest. Dominion Day 1907 formed an official, if overdue, farewell. Like New Zealand in exhibition space, the Dominion would appear as both 'new' and 'modern', distanced from 'colonial' time and space. Time ran in reverse, as the Dominion grew younger, not older. Celebrations and their associated rhetoric spoke of the 'passing' of 'old' New Zealand. In Dunedin, the Last Post was played as 'requiem', for 'New Zealand as a colony, with its trials, triumphs and affectionate associations, was irrevocably passing away'. ${ }^{70}$ The term 'colony', as the Bush Advocate noted, was truly a 'thing of the past'. ${ }^{71}$ With the assumption of Dominion status, it was claimed, 'the word, colony and the things pertaining thereto had been put away in the great archive of the splendid past'. ${ }^{72}$

One of the things 'pertaining thereto' was Māori. Though Māori culture could be appropriated as a 'native signature' to create a distinctive New Zealand identity, it was troubling in the construction of Dominion-ness, where it might reinforce unwanted links with the peripheral past. ${ }^{73}$ Dominion status underwrote progress from 'savagery to nationhood', meaning 'savages' were no longer required. ${ }^{74}$ The conundrum of their actual existence was managed again by minimization and containment. In Wellington, where the most elaborate construction of Dominionhood was staged, they had no official role, though a Māori face was 'noted here and there'. ${ }^{75}$ The press chose to interpret their insignificance as a virtue, 'symbolizing the unity of the races' ${ }^{76}$ In the few instances where Māori were incorporated, their presence was contained. Māori were prominent in Rotorua's celebrations. With its wild landscapes and wild people, Rotorua already acted as New Zealand's living museum. In this permanent quarantine zone for anachronism, amongst geysers and contrived Māori villages, some 'very exultant' natives would do no harm; even less as they were tamed and historicized by being associated with Gilbert Mair and described as having 'fought for the British flag against their tribesmen'. ${ }^{77}$ 
However, Māori themselves did not always stay neatly in their assigned place as the disappearing symbols of a fast vanishing past. Some, visiting the capital, intruded on the careful excision of the past by staging an impromptu haka 'just as the crowds were dispersing' at the close of the official function. ${ }^{78}$ In Kaiapoi, 'a few Maoris in full dress' may have been a quaint reminder of the past, but their accompanying speech, which traced their history since Cook and included a picture of the Māori flag, suggests they may have had a different motivation. ${ }^{79}$ Other South Island iwi used that most modern method, the telegram, to send their best wishes to Parliament, embracing at every level the idea of progress that their very presence threatened.$^{80}$ But Māori were not the only markers of the past to be managed: colonialism's other dying race, the pioneers, were also archived. The modern farm foreclosed on pioneering. Despite the existence of active settlers' associations, pioneers appeared only as ghosts of the colony's past, whilst its history appeared only as a counterpoint to progress. In one instance, Henry William's son, Edward Marsh Williams, was interviewed and proclaimed as probably the last living link to the Treaty. ${ }^{81} \mathrm{He}$ was used less as evidence of an actual past than of colonialism's ephemerality. A more enduring British past could be adopted and invented in its stead. The commemoration of New Zealand's military service in South Africa was a central feature in celebrations, and served as an opportunity to integrate New Zealand within a broader 'British' history. References to Nelson and Trafalgar, and, for those who enjoyed a sense of imperial synergies, to Havelock's relief of Lucknow during the Indian Mutiny 50 years previously provided a desirable alternative to a local history that was only a 'brief chapter' in any case. ${ }^{82}$

The 'old colony' was replaced by the 'young' Dominion, 'the lovely daughter' of 'old pioneers', the 'youngest born', now at the 'front ranks of younger nations' ${ }^{83}$ The important symbols of New Zealand emphasized its 'pastlessness', creating a 'new' New Zealand. Accordingly, children became the centrepiece of celebrations. A special commemorative medal was given to every school child, and thousands of military cadets paraded in towns across the country. This, and abundant military displays, substantiated New Zealand as a young and vigorous member of empire. Children would also form the most contrived version of the 'young Dominion', in 1908 when 3000 were marshalled to create a living New Zealand ensign in Newtown Park in Wellington. ${ }^{84}$ The country's youthful progress was captured in lights. The 'New Dominion', complete with map, appeared as an illumination on the General Post Office, and the past was reduced to a hyphen in lights which read 'Advance New Zealand 1840-1907'. The use of electricity and gas to illuminate town buildings, a symbol of modernity, was significant itself. Modernity was a metropolitan, not peripheral, characteristic. Parliament buildings were decorated in Wellington, the Napier Gas Company lit the 
town around its own building with 'a brilliant electric light display, ${ }^{85}$ whilst public buildings in Dunedin were decorated with 'fairy electric arc lights. ${ }^{96}$ Nelson, not overtaken with enthusiasm, nevertheless managed a few 'strikingly' illuminated municipal buildings, whilst gas jets displayed 'God Save the King' in front of the cathedral. ${ }^{87}$

These lighted post offices, last rites and living flags were all local manifestations of Dominion status. But celebrations - even Foxton's faint cheers - belong in a broader context. Dominion status was made in the metropolis, and it expressed New Zealand's place as member of empire, not nation. Truth was right: the thinking was done in a place called London. By resuming this vantage point, this failed celebration takes on greater meaning. This also allows us to reconnect it with other similar attempts to reconstruct New Zealand identity, like exhibitions, fleshing out what seem to be representational forms (and marginal ones at that), and to explore them instead as instruments of the linked projects of identity and colonization. This is, of course, reminiscent of cultural colonization. But identity here overflowed local borders, being formed in and by a particularly intense cultural relationship centred on London. Truth also complained: 'Everything in this blessed country is borrowed. ${ }^{98}$ From the late nineteenth century, that included time and space, as New Zealand once again fashioned a new identity in, and with, the metropolis.

1 W. David McIntyre, The Commonwealth of Nations: Origins and Impact, 1897-1971, Minneapolis, 1977, p.164.

2 W. David McIntyre, Dominion of New Zealand: Statesmen and Status, Wellington, 2007, p.44.

3 McIntyre, The Commonwealth of Nations, p.164.

4 J.E. Kendle, The Colonial and Imperial Conferences, 1887-1911, London, 1967, p.8. An earlier unofficial conference was mooted in 1869 and meetings held in 1870.

5 Kendle, p.89.

6 Minutes of the 1907 Colonial Conference, Appendices to the Journals of the House of Representatives (AJHR), 1907, vol.1, A-5, p.81.

7 Ibid., p.80.

8 McIntyre, Dominion of New Zealand, p.42.

9 McIntyre, The Commonwealth of Nations, p.164.

10 McIntyre, Dominion of New Zealand, p.46.

11 Evening Post (EP), 28 June 1907, p.8.

12 Nelson Evening Mail, 28 June 1907, p.2.

13 Ibid., 8 July 1907, p.2.

14 New Zealand Free Lance, 21 September 1907, p.6.

15 Otago Daily Times (ODT), 27 September 1907, p.4.

16 Hawera and Normanby Star, 28 September 1907, p.8.

17 Poverty Bay Herald, 3 July 1907, p.2. 


\section{The Metropolis and Colonial Culture}

18 Fielding Star, 26 September 1907, p.3.

19 Allen to Ward, 8 September 1908, IA 11, box 1, Archives New Zealand (ANZ).

20 Poverty Bay Herald, 26 September 1908, p.5.

21 Parralt(?) to Hislop, 22 September 1908, IA 11, box 1, ANZ.

22 List of towns and activities, IA 11 box 1, ANZ. The list is undated, but appears to relate to 1908 arrangements.

23 Ohinemuri Gazette, 26 September, 1910, p.2.

24 Blanchard to Ward, 27 September 1910, IA 11, box 1, ANZ.

25 Hawera and Normanby Star, 27 September 1910, p.5.

26 'The "new nation" continued along the path of imperialism.' See W. David McIntyre, 'Imperialism and Nationalism', in G. Rice, ed., The Oxford History of New Zealand, 2nd edn, Auckland, 1992, p.343.

27 'The new term had symbolic value as a gesture of nationalism but it did nothing to undermine the country's allegiance to empire.' See D. Capie, 'New Zealand and the World: Imperial, International and Global Relations', in G. Byrnes, ed., The New Oxford History of New Zealand, South Melbourne, 2009, p.583.

28 'Dominion Day', ODT, 26 September 1907, p.7.

29 For a summary of the 'no change' thesis see H. Kumarasingham, 'Independence and Identity Ignored? New Zealand's Reactions to the Statute of Westminster', National Identities, 12, 2 (2010), pp.148-50.

30 N.Z. Truth, 1 October 1910, p.6.

31 For a recent review see G. Byrnes and C. Coleborne, 'Editorial Introduction: The Utility and Futility of "The Nation" in Histories of Aotearoa New Zealand', New Zealand Journal of History (NZJH), 45, 1 (2011), pp.1-14. For a decentred approach to general history see Byrnes.

32 Tony Ballantyne, 'Place, Space and Mobility in Nineteenth Century New Zealand', NZJH, 45, 1 (2011), p.63.

33 For New Zealand see James Belich, Paradise Reforged: A History of the New Zealanders from the 1880s to the Year 2000, Auckland, 2001, pp.29-31; for the Anglo world generally see Belich, Replenishing the Earth: The Settler Revolution and the Rise of the AngloWorld, 1783-1939, Oxford, 2009.

34 See C. Hilliard, 'The Provincial Press and the Imperial Traffic in Fiction', Journal of British Studies, 48, 3 (2009), p.655.

35 Peter Gibbons, 'Cultural Colonization and National Identity', NZJH, 36, 1 (2002), pp.5-17; Peter Gibbons, 'Non-fiction', in T. Sturm, ed., The Oxford History of New Zealand Literature in English, 1991, pp.25-104.

36 See Miles Fairburn, 'Is there a Good Case for New Zealand Exceptionalism', in Tony Ballantyne and Brian Moloughney, eds, Disputed Histories: Imagining New Zealand's Pasts, Dunedin, 2006, pp.143-68. Interestingly, the idea of colonial immaturity (and thus parallels with the 'nation's' maturity metaphor) is most acute when postcolonial approaches, useful in their correct contexts, are used to illuminate settler culture. Homi Bhabha's mimicry has been commonly used in this way: for a recent summary see K. Pickles, " "The Obvious and the Awkward", Postcolonialism and the British World', NZJH, 45, 1 (2011), p.87-88, 91-92.

37 Pickles, 'The Obvious and the Awkward', p.92.

38 See Carl Bridge and Kent Fedorowich, eds, The British World: Diaspora, Culture and Identity, London, Portland, 2003; Darian-Smith, Grimshaw and Macintyre. For Australia see D.M. Schreuder and S. Ward, eds, Australia's Empire, Oxford, 2008. For Canada see 


\section{Journal of New Zealand Studies}

P. Buckner, ed., Canada and the British Empire, Oxford, New York, 2008; P. Buckner and R.D. Francis, eds, Canada and the British World: Culture, Migration and Identity, Vancouver, 2006; P. Buckner, ed., Canada and the End of Empire, Vancouver, 2005. For New Zealand see Katie Pickles, 'Colonisation, Empire, and Gender', in Byrnes, pp.219-42.

39 A. Perry, 'Whose World Was British?', in K. Darian-Smith, P. Grimshaw and S. Macintyre, eds, Britishness Abroad: Transnational Movements and Imperial Cultures, Melbourne, 2008, p.35.

40 British identity, its componentry, fluidity and fixity, and its relationships to empire has a large literature: see, for contrasting examples, L. Colley's Britons: Forging the Nation, 1707-1837, New Haven and London, 1992 and C. Hall's Civilising Subjects: Metropole and Colony in the English Imagination 1830-1867, Oxford, 2002. However, it has largely not engaged with the white empire's efforts at being British: see, for example, C. Hall and S. Rose, At Home with the Empire: Metropolitan Culture and the Imperial World, Cambridge, UK and New York, 2006.

41 Anne McClintock, Imperial Leather: Race, Gender, and Sexuality in the Colonial Contest, New York, London, 1995.

42 Alan Lester, Imperial Networks: Creating Identities in Nineteenth Century South Africa and Britain, London, 2001, pp.6-7.

43 Morning Post, 21 December 1837, n.p.

44 Leonard Bell, The Maori in European Art, Auckland, 1980, p.20.

45 Robert Burford, Description of a View of the Bay of Islands, New Zealand, now exhibiting in the panorama, Leicester Square, London, 1838.

46 Ibid.

47 Robert D. Grant, Representations of British Emigration Colonization and Settlement, Houndmills, 2005, p.63. This was also a useful way of promoting British colonies over the more popular American version.

48 Jonathon Easthope, 'Imaging Ourselves: The Projection of Pakeha Culture Overseas 1870-1925', MA thesis, Victoria University of Wellington, 1995, p.19; E.C. Johnston, 'Representing the Pacific, 1851-1940', PhD thesis, University of Auckland, 1999, p.216.

49 Johnston, 'Representing the Pacific', p.216.

50 E.C. Johnston, 'New Zealand at the Crystal Palace', in J. Auerbach and P. Hoffenberg, eds, Britain, the Empire and the World at the Great Exhibition of 1851', Aldershot, 2008, p.89.

51 IA 25 1/2, Vienna packing lists, ANZ.

52 Ibid.

53 Circular from the Colonial Secretary to the Superintendents of the Provinces, Wellington, 15 April 1875, the Philadelphia Exhibition of 1876, AJHR, 1875, H-5, no.12, p.5, quoted in Johnson, 'Representing the Pacific', p.231.

54 'Our London Letter', Evening Post, 30 July 1884, p.3.

55 Ibid.

56 See Hoffenberg, An Empire on Display, p.106 and fig. 4; also Easthope, 'Imaging Ourselves', p.23.

57 Colonial and Indian Exhibition, London, Catalogue of New Zealand Exhibits.

58 Colonial and Indian Exhibition, London 1886, Official Catalogue, p.45.

59 The Times, 8 May 1908, p.20.

60 'High Commissioner of New Zealand's Report for the Year Ending 31 March 1912', AJHR, 1912, H-28, p.4. 


\section{The Metropolis and Colonial Culture}

61 Colonial and Indian Exhibition, London, Catalogue of New Zealand Exhibits, p.xv.

62 Minutes of the Meeting of New Zealand Commissioners held at the Colonial and Indian Exhibition, Monday 12 July, 1886, p.3, Haast Family Papers, MS-Papers-0037-001, Alexander Turnbull Library (Wellington), quoted in Johnston, 'Representing the Pacific', p.262.

63 'The Colonial and Indian Exhibition: New Zealand', The Times, 24 July 1886, quoted in ibid.

64 EP, 6 July 1911, p.11.

65 Māori use and interpretation of exhibition space worked differently. For the 1906 Christchurch Exhibition see Bernard Kernot, 'Maoriland Metaphors and the Modern Pa', in John Mansfield Thomson, ed., Farewell Colonialism: The New Zealand International Exhibition Christchurch, 1906-07, Palmerston North, 1998, pp.61-78. For colonial cultures of display generally see C. McCarthy, Exhibiting Maori: A History of Colonial Cultures on Display, Wellington, 2007.

66 Benedict Anderson, Imagined Communities: Reflections on the Origin and Spread of Nationalism, rev. edn, London, New York, 2006, p.11.

67 The Times, 12 January 1911, p.6.

68 Ibid., 24 January 1911, p.10.

69 Graphic, 8 May 1886, p.495, quoted in Hoffenburg, p.25.

70 ODT, 26 September 1907, p.3.

71 Bush Advocate, 26 September, 1907, p.4.

72 ODT, 27 September 1907, p.2.

73 Ben Dibley, 'Telling Times: Narrating Nation at the New Zealand International Exhibition 1906-7', Sites, 3 (1997), pp.1-18.

74 Dominion, 26 September 1907, p.6.

75 Ward proposed a toast to the 'Maori race' at Bellamy's on the eve of Dominion status: Poverty Bay Herald, 26 September 1907, p.5.

76 EP, 26 September 1907, p.7.

77 Ibid.

78 New Zealand Herald (NZH), 27 September 1907, p.6.

79 Probably the United Tribes flag, as it was compared to the New Zealand ensign, the naval version of which is white: Star, 26 September 1907, p.3.

80 AJHR, 1907, vol.1, A-7.

81 NZH, 26 September 1907, p.7.

82 ODT, 26 September 1907, p.4.

83 From a poem, 'Our Young Dominion', Otago Witness, 25 September 1907, p.5; Grey River Argus, 27 September 1907, p.4; ODT, 27 September 1907, p.3.

84 'Dominon Day Flyer', 1908, IA 11, box 1, ANZ.

85 Wanganui Herald, 25 September 1907, p.5.

86 NZH, 27 September 1907, p.7.

87 Nelson Evening Mail, 27 September 1907, p.2.

88 N.Z. Truth, 1 October 1910, p.6. 
Journal of New Zealand Studies 